\title{
Diversity of alternative hosts of maize stemborers in Trans-Nzoia district of Kenya
}

\author{
James I. KANYA ${ }^{1}$, Adele J. NGI-SONG ${ }^{2}$, Mamoudou F. SÉTAMOU ${ }^{3}$, William OVERHOLT ${ }^{4}$, John OCHORA ${ }^{1}$ \\ and Ellie O. OSIR ${ }^{2 *}$ \\ ${ }^{1}$ Jomo Kenyatta University of Agriculture and Technology, P.O. Box 62000, Nairobi, Kenya \\ ${ }^{2}$ International Centre of Insect Physiology and Ecology (ICIPE), P.O. Box 30772, 00100 GPO, Nairobi, Kenya \\ ${ }^{3}$ ARS-USDA Beneficial Insects Research Unit, Weslaco, TX 78596, USA \\ ${ }^{4}$ University of Florida, 2129 South Rock Road, Fort Pierce, FL 34945, USA
}

\begin{abstract}
Genetically-engineered (GE) crops such as those expressing insecticidal Bacillus thuringiensis (Bt) toxin genes have the potential to greatly reduce the use of broad spectrum insecticides and increase crop productivity. However, development of resistance by the target insect species is an important consideration in the deployment of this strategy. In areas where GE crops are deployed on a large scale, current resistance management strategies rely on a 'refuge strategy', comprising the incorporation of a certain proportion of nonGE plants in the agro-ecosystems, to conserve susceptible individuals of the target pests. In the USA, simulation models indicate that at least $20 \%$ of the crop should be non-Bt plants. In Africa, the target lepidopteran stemborers attack a wide range of wild grass species as well as cultivated cereal crops. Wild grasses generally occur in the vicinity of maize and other cereal fields, and may provide a refuge if GE crops are in the farming systems. To assess the quality of these grasses as refuges, it is critical to obtain information about their size and spatial distribution. In this study, we have assessed the abundance and diversity of alternative refuge of stemborers, mainly wild grasses occurring in the proximity of maize fields, in Trans-Nzoia district, one of the most important maize growing areas in Kenya. The proportion of wild host plants relative to maize was found to decline from $100 \%$ during the non-cropping season to $<8 \%$ during the maize-growing season. The ShannonWeaver diversity index indicated high variation in the diversity of wild hosts of stemborers between agroecological zones in the district. The results of this study are discussed in light of the possible role that wild host plant species might play in stemborer resistance management following the introduction of $B t$ maize.
\end{abstract}

Keywords: Bacillus thuringiensis / maize / stemborers / resistance / refuge / wild host plants / agro-ecological zones

\section{INTRODUCTION}

Cereals such as maize are critical to the economies of many African countries as they constitute a primary commodity of agricultural development. Unfortunately, cereal production is compromised by losses due to preand post-harvest arthropod pests. In Africa, maize yield losses directly attributable to a complex of lepidopteran stemborers alone range from $15 \%$ to $40 \%$ (KARI/ CIMMYT, 2001). Proportions of these stemborers feed on cereal crops and various native grass species. During offseason when cereal crops are not present in the fields, these grasses, and crop stubble, are the only refuges for the stemborers. The two most important stemborers in East and southern Africa are Chilo partellus Swinhoe (Lepidoptera: Crambidae) and Busseola fusca Fuller (Lepidoptera: Noctuidae).

Past efforts to mitigate pre- and post-harvest losses have relied upon synthetic pesticides. However, their use has become increasingly inappropriate due to their high cost, rapid resistance development and environmental pollution. Alternative management approaches are needed that are both effective and sustainable. Examples include habitat management for stemborer control in maize-based

\footnotetext{
* Corresponding author: eosir@icipe.org
} 
cropping systems and classical biological control for the exotic C. partellus (Khan et al., 1997; Overholt et al., 2003). In addition, the use of biotechnology to develop resistant crop varieties promises to be an effective additional tool with great potential for contributing towards food security in Africa (Persley, 2002). Indeed, transgenic maize expressing $B t$ toxin genes has been shown to be nearly immune to attack by stemborers (Koziel et al., 1993).

A large number of insect species have already developed resistance to conventional insecticides, and to several $B t$ toxins (Tabashnik et al., 1995). Unless appropriate management strategies are developed and implemented, the deployment of GE crops (such as Bt maize) will almost certainly lead to the emergence of resistant stemborer populations. Most scientists agree that the high dose/refuge strategy is the best method to delay resistance evolution (Brousseau et al., 1999). This strategy includes the use of transgenic crops that express highly toxic levels of the insecticide in all plant parts, throughout the season, such that nearly all of the susceptible individuals (SS) and heterozygous individuals (SR), feeding on the GE crop are killed. The refuge component of the strategy requires that non-GE plants are available in the cropping system, or nearby, so that susceptible individuals survive to mate with any resistant homozygous individuals (RR) surviving in the GE plants (Gould and Tabashnik, 1998). Since African cereal stemborers feed not only on crops (e.g. maize and sorghum), but also attack various native wild grasses, which often occur near cropping environments, important questions are: (i) will these "wild reservoirs" serve as adequate refuges for the development of a sufficient number of susceptible individuals?, and (ii) will the individuals developing in these native habitats mix sufficiently with individuals developing in GE crops? In the USA, where $B t$ maize is planted, simulation models indicate that $20-50 \%$ of the total planted area be non-transgenic plants. In Africa, this may be necessary as well, but natural hosts of these stemborers in the families Poaceae, Cyperaceae and Typhaceae (Khan et al., 1997), may serve as refuges. To fully develop this strategy, basic ecological information is needed on the species composition, abundance, spatial distribution, and temporal occurrence of natural "refuges". A large amount of the work on refuges of stemborers has been conducted in the USA, where the target stemborer populations are mostly univoltine or bivoltine (Overholt et al., 1994) and monocultures of maize dominate the landscape. These studies have focused on the cultivated host plants of stemborers. However, in tropical and sub-tropical Africa the situation is significantly different. Large monocultures of maize are seldom found and maize fields are generally surrounded by natural habitats that could serve as reservoirs and refuges (Schulthess et al., 1997). Pest populations often breed continuously throughout the year. Chilo partellus may have three generations during each of the two cropping seasons; AprilAugust and October-December in bimodal rainfall areas (Overholt et al., 1994), with additional generations in wild grasses between seasons (Scheltes, 1978).

The aim of the present study was to quantify the abundance and diversity of natural host plants of stemborers that could serve as alternative refuges in the Trans-Nzoia district, one of the most important maize production areas in Kenya. As a leading region for largescale maize production, it is likely to be among the first to be considered for introduction of $B t$ maize in Kenya. Greater diversity of alternative host plants would increase the proportion of hosts available to the stemborers throughout the season. Also, once the diversity indices for a given area are known, the information could be used together with measures of stemborer survival on alternative hosts to estimate pest population levels on wild host plants versus maize.

\section{RESULTS}

\section{Wild hosts within the different agro-ecological zones of Trans Nzoia}

Trans-Nzoia is one of the leading maize producing districts in Kenya with a production of 245000 metric tones in 1990 (FAO, 2001). The district (covering $2468 \mathrm{~km}^{2}$ ) is situated in western Kenya approximately between longitudes $34^{\circ}, 23^{\circ} \mathrm{E}$ and $0^{\circ}, 1^{\circ} \mathrm{N}$ (Fig. 1); the lowest altitude is $1600 \mathrm{~m}$ and the highest $3800 \mathrm{~m}$. The district has a highland equatorial climate with maximum and minimum temperatures ranging from $13-29{ }^{\circ} \mathrm{C}$ and 2-13 ${ }^{\circ} \mathrm{C}$, respectively (Jaetzold and Schmidt, 1982). The slopes of Mt. Elgon to the west and Cherengani Hills to the northeast receive the highest annual rainfall amounts $(1600 \mathrm{~mm})$, while the regions bordering West Pokot district receive the lowest rainfall (970 $\mathrm{mm}$ per annum). Of the 14 distinct agro-ecological zones (AEZ), 9 in which maize is grown were used in this study (Fig. 1).

The locations of the sampling sites surveyed are shown in Figure 1. The nine agro-ecological zones in which maize was grown in 1997 were determined using data from the Department of Resource Surveys and Remote Sensing (Sombroek and Antoine, 1994). Arc View 3.2 software (1992) was used to divide the sampling area into identical polygons and assign 192 possible equidistant sampling points. From these points, a sample size of 


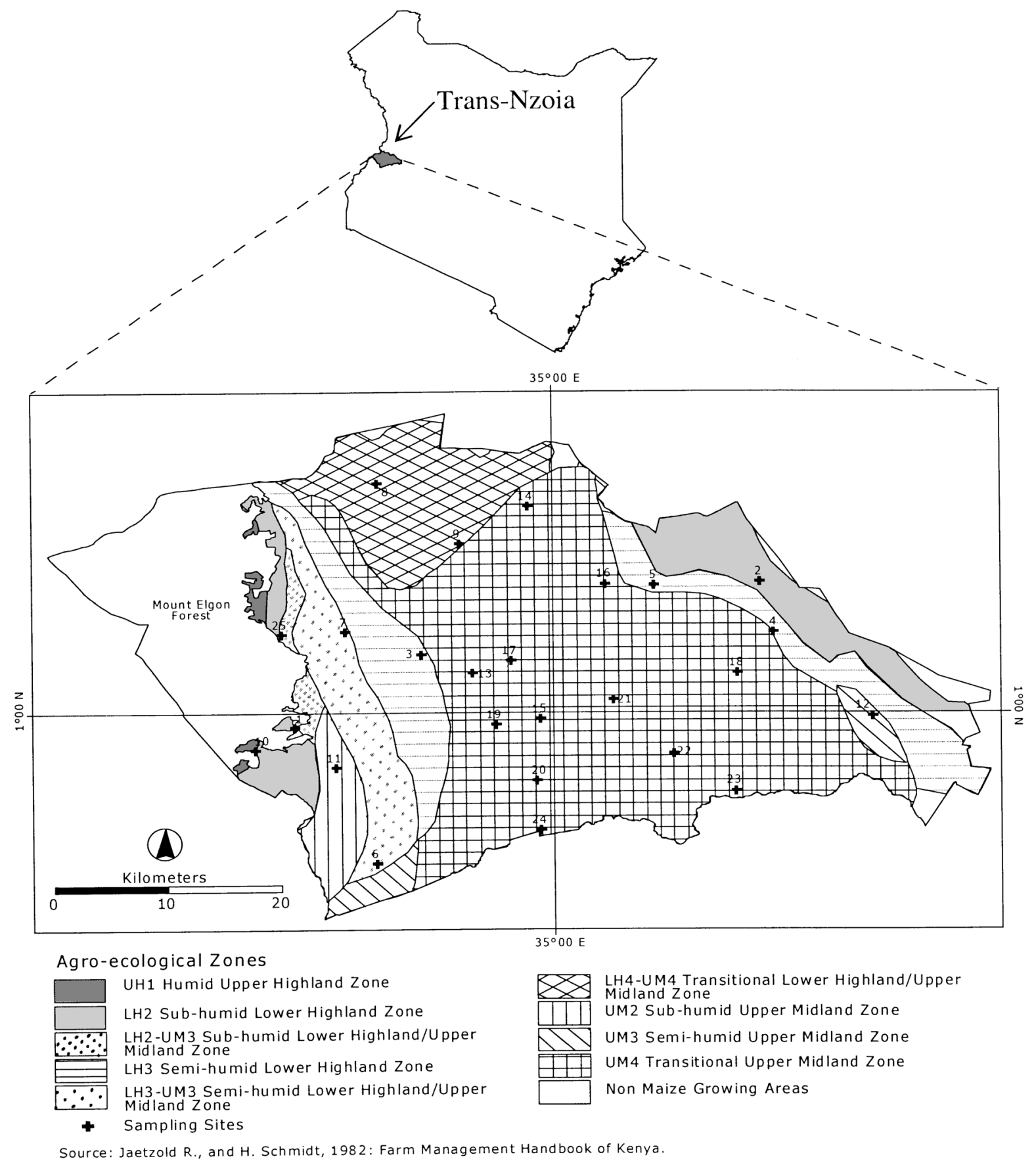

Figure 1. Map of Kenya showing Trans-Nzoia district and the sampling points.

25 sites was determined using the equation by Webster and Oliver (1990) as follows:

$$
n=\frac{z^{2}}{I^{2}} p q
$$

where $n=$ sample size; $I=$ permitted error $(0.1) ; z=$ confidence interval (1.15); $p=$ probability of the area covered by maize (70\%); and $q=$ probability of the area not covered by maize (30\%) in the district. The $p$ and $q$ 
Table 1. Wild host plants recorded in the various agro-ecological zones (AEZs).

\begin{tabular}{|c|c|c|c|c|c|c|c|c|c|}
\hline \multirow[b]{2}{*}{ Wild host plant species } & \multicolumn{9}{|c|}{ Agro-ecological zones } \\
\hline & UH1 & $\mathrm{UM} 2$ & UM3 & UM4 & LH2-UM3 & LH3-UM3 & LH4-UM4 & LH2 & LH3 \\
\hline \multicolumn{10}{|c|}{ Andropogon abyssinicus Fresen. } \\
\hline \multicolumn{10}{|c|}{ Cyperus immensis Delile } \\
\hline \multicolumn{10}{|c|}{ Echinochloa haploclada (Stapf) } \\
\hline \multicolumn{10}{|c|}{ Hyparrhenia cymbaria } \\
\hline \multicolumn{10}{|c|}{ Echinocloa pyramidalis (Lam.) } \\
\hline \multicolumn{10}{|c|}{ Hitch. \& Chase } \\
\hline \multirow{2}{*}{\multicolumn{10}{|c|}{ Hyparrhenia filipendula }} \\
\hline \multirow{2}{*}{\multicolumn{10}{|c|}{ H. rufa (Nees) Stapf }} \\
\hline \multirow{2}{*}{\multicolumn{10}{|c|}{ Panicum maximum Jacq. }} \\
\hline & & & & & & & & & \\
\hline \multicolumn{10}{|c|}{ Pennisetum purpureum Schumach. } \\
\hline \multicolumn{10}{|c|}{ P. trachyphyllum Pilger } \\
\hline \multicolumn{10}{|c|}{ Setaria sphacelata (Schumach.) Moss } \\
\hline \multicolumn{10}{|c|}{ Sorghum arundinaceum (Desv.) Stapf } \\
\hline \multicolumn{10}{|c|}{ Sporobolus pyramidalis Beauv. } \\
\hline Typha domingensis Pers. & & & & & & & & & \\
\hline
\end{tabular}

UH1: humid upper highland zone; UM2: sub-humid upper midland zone; UM3: semi-humid upper midland zone; UM4: transitional upper midland zone; LH2-UM3: sub-humid lower highland/upper midland zone; LH3-UM3: semi-humid lower highland/upper midland zone; LH4-UM4: transitional lower highland/upper midland zone; LH2: sub-humid lower highland zone; LH3: semi-humid lower highland zone.

values were obtained from the Kenya government's "Department of Survey and Remote Sensing" report of 1997.

Specific sites were randomly selected in the zones. The number of sampling sites in each zone was proportional to the relative size of the zone in the study area (Fig. 1). Coordinates were determined using a hand-held Geographical Positioning System (GPS) (Garmin 12). The wild host species recorded in the various AEZs are shown in Table 1. Zone UM4 had the highest number of the plant species while LH4-UM4 had the lowest.

\section{Proportion of maize to wild host plants}

The proportion of maize relative to wild hosts of stemborers varied with the sampling period and the agroecological zones (Tab. 2a). During the cropping period (March to October), maize represented more than half of the potential host plants in all the zones except in LH2 and UH1. No data was collected in UH1 in May since the selected sampling points fell in Mt. Elgon National Park, which is a restricted area. These points were later relocated to other areas in subsequent surveys (July, September and February). In zone LH2, the proportion of maize relative to wild host plants varied from 0 to a maximum of $18.9 \%$.
Similarly, maize crown cover did not exceed $37.5 \%$ in zone UH1 on all sampling occasions. In February 2003, wild host plants constituted the sole food source for stemborers in all the zones with the exception of zone UM4 in which maize represented $3.4 \%$ of the total host plants. From the $\chi^{2}$ values (Tab. $2 b$ ), the overall proportion of maize crown cover relative to wild host plants varied greatly. The proportion of maize increased from $61 \%$ in May 2002 to a maximum of $92 \%$ in July 2002, and then dropped to less than $10 \%$ in February 2003 (Fig. 2).

\section{Evenness of wild host plants}

Wild host plant evenness varied with sampling period and agro-ecological zone. At the beginning of the study in May 2002, the highest evenness of wild host plants was recorded in zone UM3 $\left(\mathrm{E}_{\mathrm{H}}=0.86\right)$, while the lowest $\left(\mathrm{E}_{\mathrm{H}}=0.6\right)$ was recorded in zone UM2 $(\mathrm{t}=3.34 ; P<0.05$; $\mathrm{df}=11$; Fig. 3). A significantly more even distribution of wild host plants was found in zone UM2 $\left(\mathrm{E}_{\mathrm{H}}=0.97\right)$ in July 2002, compared to the other zones $(\mathrm{t}=10.1 ; P<0.05$; $\mathrm{df}=8$; Fig. 3); zone LH2 had the lowest host plant evenness $\left(E_{H}=0.58\right)$. During the dry season of February 2003, values of host plant evenness ranged from 0.98 in 
Wild host plants of stemborers in Trans-Nzoia district

Table 2a. Crown cover of maize and wild host plants.

\begin{tabular}{|c|c|c|c|c|c|c|c|c|c|c|}
\hline Zones & UH1 & UM2 & UM3 & UM4 & LH2-UM3 & LH3-UM3 & LH4-UM4 & LH2 & LH3 & Total \\
\hline \multicolumn{11}{|l|}{ May 2002} \\
\hline Maize & - & 2.97 & 2.85 & 50.04 & - & 7.61 & 6.33 & 0.00 & 7.68 & 77.47 \\
\hline Wild host plants & - & 3.61 & 1.54 & 13.03 & - & 14.58 & 1.14 & 6.54 & 9.61 & 50.05 \\
\hline$\%$ Maize cover & - & 45.11 & 64.92 & 79.34 & - & 34.29 & 84.74 & 0.00 & 44.4 & 60.75 \\
\hline$\%$ Wild host plants cover & - & 54.89 & 35.08 & 20.66 & - & 65.71 & 15.26 & 100.00 & 55.59 & 39.25 \\
\hline \multicolumn{11}{|l|}{ July 2002} \\
\hline Maize & 1.27 & 35.07 & 4.36 & 159.11 & 3.64 & 12.60 & 15.71 & 1.40 & 29.78 & 262.96 \\
\hline Wild host plants & 2.11 & 0.90 & 2.65 & 4.39 & 0.30 & 1.71 & 0.42 & 6.03 & 5.53 & 24.04 \\
\hline \% Maize cover & 37.50 & 97.50 & 62.20 & 97.32 & 92.38 & 88.05 & 97.40 & 18.98 & 84.34 & 91.62 \\
\hline$\%$ Wild host plants cover & 62.50 & 2.50 & 37.80 & 2.68 & 7.62 & 11.95 & 2.60 & 81.02 & 15.66 & 8.38 \\
\hline Zones & UH1 & UM2 & UM3 & UM4 & LH2-UM3 & LH3-UM3 & LH4-UM4 & LH2 & $\begin{array}{l}\text { LH3 } \\
\end{array}$ & Total \\
\hline \multicolumn{11}{|l|}{ September 2002} \\
\hline Maize & 2.18 & 13.13 & 10.07 & 186.65 & 1.27 & 15.27 & 15.46 & 0.24 & 35.88 & 280.16 \\
\hline Wild host plants & 4.06 & 0.51 & 5.10 & 3.12 & 0.38 & 3.37 & 1.62 & 3.99 & 7.58 & 29.73 \\
\hline$\%$ Maize cover & 34.95 & 96.26 & 66.38 & 98.36 & 76.95 & 81.92 & 90.52 & 5.77 & 82.56 & 90.41 \\
\hline$\%$ Wild host plants cover & 65.05 & 3.74 & 33.62 & 1.64 & 23.05 & 18.08 & 9.48 & 94.23 & 17.44 & 9.59 \\
\hline \multicolumn{11}{|l|}{ February 2003} \\
\hline Maize & 0.00 & 0.00 & 0.00 & 2.86 & 0.00 & 0.00 & 0.00 & 0.00 & 0.00 & 2.86 \\
\hline Wild host plants & 0.74 & 1.32 & 1.61 & 2.95 & 0.80 & 5.13 & 2.73 & 8.53 & 5.16 & 28.97 \\
\hline$\%$ Maize cover & 0.00 & 0.00 & 0.00 & 3.37 & 0.00 & 0.00 & 0.00 & 0.00 & 0.00 & 8.99 \\
\hline$\%$ Wild host plants cover & 100.00 & 100.00 & 100.00 & 96.63 & 100.00 & 100.00 & 100.00 & 100.00 & 100.00 & 91.01 \\
\hline
\end{tabular}

The values are the total crown cover $(\mathrm{cm})$ for maize and wild host plants obtained from the transect lines in each agro-ecological zone (Fig. 1) during the four sampling periods.

Table 2b. Levels of variation of maize to wild host plants in different agro-ecological zones.

\begin{tabular}{lcccccccccc}
\hline \hline & \multicolumn{10}{c}{ Agro-ecological zones } \\
\hline Sampling months & UH1 & UM2 & UM3 & UM4 & LH2-UM3 & LH3-UM3 & LH4-UM4 & LH2 & LH3 & Total \\
\hline May & - & 3.53 & 8.90 & 34.44 & - & 57.91 & 48.27 & 100.00 & 1.25 & 81.99 \\
July & 6.25 & 89.86 & 5.96 & 89.55 & 71.84 & 29.15 & 90.24 & 38.49 & 47.17 & 69.30 \\
September & 9.06 & 65.67 & 10.73 & 93.53 & 29.06 & 40.75 & 85.61 & 78.24 & 42.41 & 65.31 \\
February & 100.00 & 100.00 & 100.00 & 86.97 & 100.00 & 100.00 & 100.00 & 100.00 & 100.00 & 81.99 \\
\hline
\end{tabular}

The Chi-square $\left(\chi_{2}^{2}\right)$ values were calculated from data presented in Table $2 \mathrm{a} . \alpha=0.05 ; \mathrm{df}=1 ;-=$ data not collected. There is significant difference when $\chi^{2}$ is greater than 3.84 .

zone UM3 to 0.72 in zone LH2. Intermediate values of host plant evenness were recorded in LH2-UM3, LH4-UM4 UH1 and UM2, but these zones had significantly more diverse stemborer host plants compared to LH3-UM3, UM2 and LH3 (t = 2.55; $P<0.05$; df =12; Fig. 3).

\section{Wild host plant diversity}

The diversity of wild host species or species richness (Magurran, 1988) varied significantly between the various agro-ecological zones in Trans Nzoia district (Fig. 3). The Shannon diversity index varied from 1.8 in zone UM4 


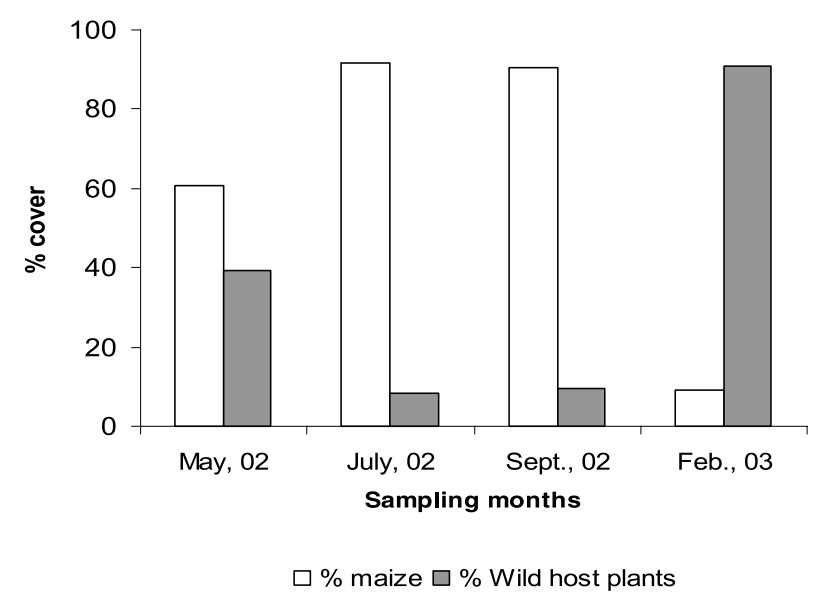

Figure 2. Percentage cover of maize and wild host plants at different sampling periods (months) in Trans-Nzoia district.

during the July sampling to 0.1 in zone LH4-UM4 in September. In 3 of the 4 sampling periods, zone UM4 had the highest wild host plant diversity, whereas zone LH4-
UM4 had the lowest index at all sampling periods. In September 2002, wild host plant diversity varied from the highest value of 1.69 in zone UM4 to the lowest value of 0.14 in zone LH4-UM4 ( $\mathrm{t}=2.10 ; P<0.05 ; \mathrm{df}=8$; Fig. 3 ). The remaining zones, that is, LH3-UM3, LH3, LH2 and $\mathrm{UM} 2$, had intermediate indices during the entire sampling period (Fig. 3).

\section{DISCUSSION}

In Trans-Nzoia district, 14 stemborer wild host plants were recorded in addition to maize. The year-round presence of these wild host plants suggested that stemborers could continuously breed, thus allowing several generations per year (Overholt et al., 1994). This is because the wild host plants may be present at different times thus a greater diversity would increase the likelihood of some host plants being available throughout the year. However, B. fusca enters an obligatory diapause during the noncropping season in senescent plants, while $C$. partellus either diapauses or continues to develop, depending on

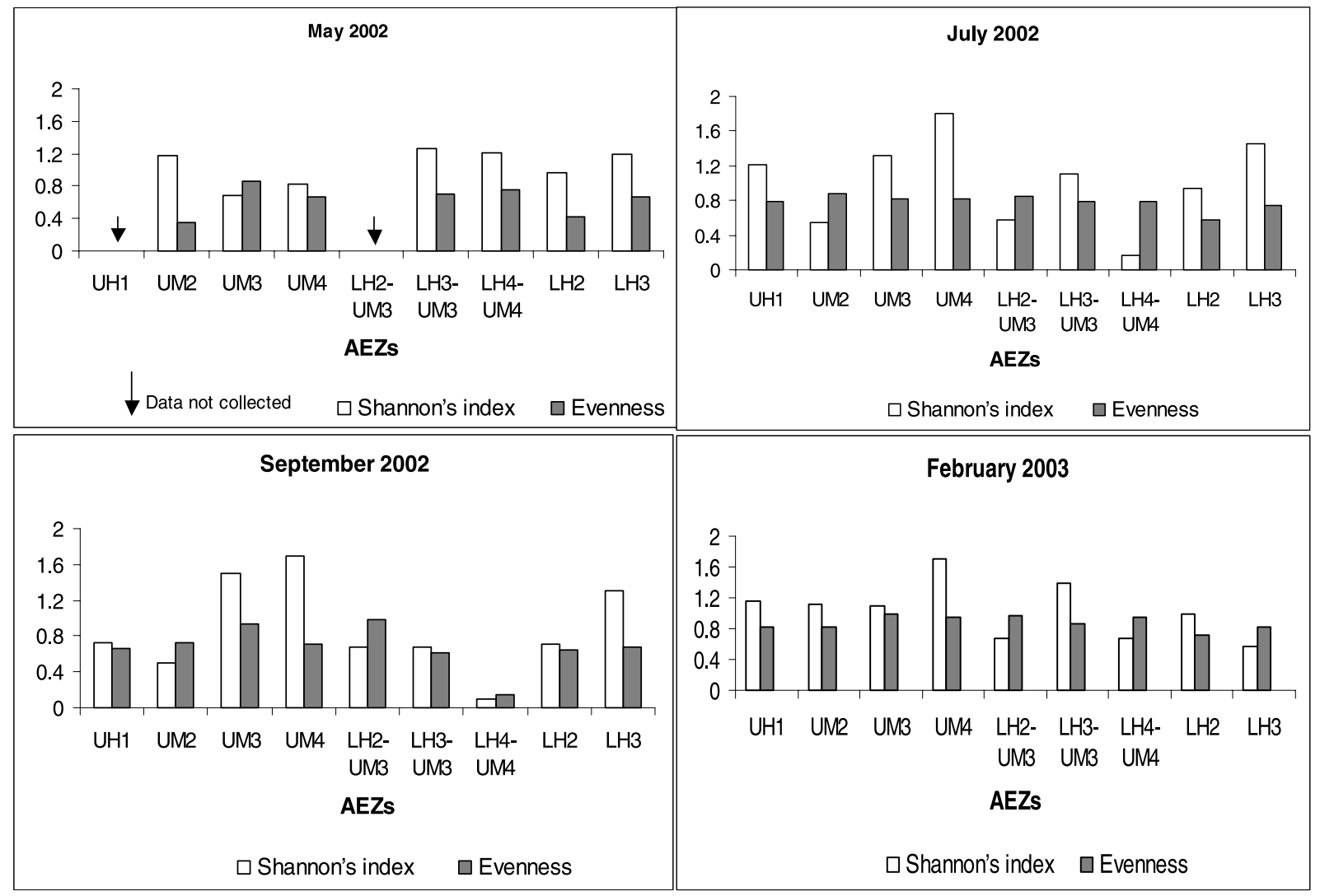

Figure 3. Shannon-Weaver Diversity Index and Shannon's Evenness Index of wild host plants in the agro-ecological zones at different sampling periods. 
host plant quality. Thus, the availability of wild host plants during non-cropping seasons may differentially affect resistance development in these two stemborers.

Species richness and abundance of the wild host plants greatly varied with agro-ecological zone and sampling period. The reasons for the differences in zonal balance of host plants are not known but may be related to elevation, rainfall, vegetation types and soil characteristics. Additionally, other factors such as habitat size may also affect species diversity (Williams, 1964). Zone UM4 is the most extensive zone in the district, occupying about $55 \%$ of total area, with annual rainfall ranging from 1700-1950 $\mathrm{mm}$, the highest in the district. Wild host plants also thrive well on its fertile and well-drained soils (Jaetzold and Schmidt, 1982). The low diversity indices recorded in zone LH4-UM4 on the other hand, could be attributed to aridity and shallow infertile soils; this zone has the lowest precipitation in the district with an annual rainfall ranging from 900 to $1050 \mathrm{~mm}$ (Jaetzold and Schmidt, 1982). Zone UM3 had the highest evenness of wild host plants. The Upper Midland (UM) agro-ecological zones are the major farming areas of the district, thus farming practices such as the use of chemical fertilizers could conceivably favor the growth of weeds including grass species and sedges. As reported by Rebe and Van den Berg (2001), farming practices also affect plant species distribution, with host species such as wild sorghum invading abandoned maize fields or fallow fields. Unlike fertilizers, the use of herbicides could selectively affect wild host plant diversity and abundance. Sullian et al. (1998) showed that grass species richness is reduced following application of glyphosphate herbicide, and remained low for up to five years.

During the non-cropping season in February, wild host plants are the sole food source of active stemborer populations. These host plants found in the system when maize is not available facilitate the carry-over of stemborers from one cropping season to the next and may be conducive to the survival of susceptible stemborer individuals from the previous cropping season, particularly for C. partellus which may continue to breed in the non-cropping season.

During the cropping season however, the proportion of maize to wild host plants varied from $60 \%$ to more than $90 \%$, thus making this crop the most important host plant from May to September. In areas with large monocultures of maize, the general recommendation is to plant $20-50 \%$ of the area with non- $B t$ maize to delay the development of resistance (Brousseau et al., 1999). In spite of their diversity, wild host plants in the Trans-Nzoia district covered a substantially lower proportion of the landscape compared to maize during the active cropping period.
Thus, considering solely the crown cover, additional refuge may be required to delay the onset of resistance development in stemborer populations.

Differential host preference for oviposition and larval development is well known in stemborer species. Host plants such as Pennisetum purpereum and P. trachyphyllum are known to be more attractive than maize for oviposition of B. fusca and C. partellus (Khan et al., 1997; Ndemah et al., 2002). Schulthess et al. (1997) also showed that two other stemborers, Sesamia calamistis Hampson and Eldana saccharina Walker, were more attracted to wild host plants such as Hyparrhenia rufa, Pennisetum polystachion and Andropogon sp. than to maize for oviposition. Because of their attractiveness, some of these wild host plants have been used in stemborer management practices as trap plants bordering maize crops (Khan et al., 1997; Ndemah et al., 2002). In most of these studies, the area covered by the trap crop did not exceed $5 \%$ of the total area, while maize represented more than $95 \%$. The attractiveness of these host plants relative to maize may depend of the distance between the crop and the wild hosts. In natural vegetation such as was encountered during the surveys, wild host plants are scattered, a factor which may limit their role as trap plants. There is currently very little information about the distances traveled by stemborers to find their mates. The two attractive wild host plants recovered during the surveys, $P$. purpureum and $P$. maximum, are cultivated throughout the tropics and sub-tropics for fodder; they produce large quantities of palatable herbage and are regarded as pasture grasses of excellent quality (Innes and Kay, 1977). In Kenya, P. purpureum is also planted as a trap plant in stemborers management (Khan et al., 2000).

Despite a higher attractiveness of certain wild host plant species to ovipositing females, poor larval performance has been recorded in most of these plants compared to maize (Khan et al., 2000; Ofomata et al., 2000; Schulthess et al., 1997). On maize, more than $70 \%$ of the stemborer larvae pupated, while less than $30 \%$ of larvae reached the pupal stage on some wild grass species (Schulthess et al., 1997). Khan et al. (2000) reported that $C$. partellus and B. fusca larval survival was close to zero on napier grass, $P$. purpureum. In a recent study however, 20-40\% C. partellus larvae were found to pupate on wild grass species comprising $P$. purpureum, S. arundinaceum and $H$. rufa, but these pupation rates were significantly lower than those recorded on maize (Sétamou, unpublished data). Because of its higher nitrogen content, maize is generally more succulent and nutritious than many wild grass species, thus providing a better food source for stemborers (Sétamou et al., 1993). 
Although more stemborer eggs may be laid on some wild host plant species due to a higher oviposition preference, substantially fewer larvae will reach adulthood on these plants compared to maize. Overall, the number of adults emerging from natural habitats compared to those from maize, will depend not only on the relative abundance of wild host plants, but also on their quality, that is, factors such as host preference for oviposition and larval performance. Additional work is needed to determine the proportion of stemborer eggs laid on wild host plants and the percent adult emergence as well as the sex ratio of individuals emerging on these wild host plants in comparison to maize. The current study showed that the ratio of wild host plants to maize was below $10 \%$ during part of the year, and therefore may be inadequate to sustain susceptible stemborers. Further research is needed to find possible supplements for the deficit. In addition, research on adult stemborer dispersal from pupation sites to mating sites is required in order to understand the influence of the maize/wild host plants spatial pattern on mating frequency.

\section{MATERIALS AND METHODS}

\section{Establishment of the baseline and number of the sampling (transect) lines}

The transect intercept method of sampling was employed (Grieg-Smith, 1983). At each sampling site, a $1 \mathrm{~km}$ baseline with a west-east orientation was established. Three points were randomly placed along this baseline through which a sampling line (transect) passed. Three transect lines (each $50 \mathrm{~m}$ ) were established which intersected the baseline at their midpoints (William, 1996). The orientation for each transect was randomized by selecting a number between $0^{\circ}$ and $360^{\circ}$.

\section{Measurements on each line}

As the line was traversed, the wild host species intercepted by the transect line were identified to produce a species list (Agnew and Agnew, 1994; Beentje, 1994). Where field identification of a species was not possible, a voucher specimen was collected for later identification at the herbarium of the National Museums of Kenya. The crowncover (the proportion of ground occupied by a perpendicular projection of the aerial parts of the individual plant species) for each intercepted plant species was also noted (Grieg-Smith, 1983). The estimated cover of all the wild host species over the entire transect was taken by measuring the distance (in $\mathrm{cm}$ ) of transects intercepted by individual plant species (Thenya, 2001). The intercept lengths of each plant species along the total number of transects in a particular agro-ecological zone were summed. This gave the fraction of the section occupied by each species in that agro-ecological zone. The proportion of crown-cover by each species relative to the total crown cover of all host plant species was subsequently derived (Patil and Taillie, 1977).

\section{Data analysis}

The diversity of wild host plant species in the district was determined by the Shannon-Weaver diversity index (H') using the following formula:

$$
-\sum_{i=1}^{k} p_{i} \ln \left(p_{i}\right), \text { where } p_{i}=N_{i} / N
$$

where $i=$ host plant species; $p_{i}=$ proportion of the observations found in host plant species I; $N=$ the total crown cover; and $N_{i}=$ the crown cover for a specific host plant species, then $p_{i}=N_{i} / N$. The observed diversity was further expressed as the proportion of maximum possible diversity (Zar, 1999). Thus, relative diversity or Shannon's evenness $\left(\mathrm{E}_{\mathrm{H}}\right)$ was calculated as follows: $\mathrm{E}_{\mathrm{H}}=\mathrm{H}^{\prime} / \mathrm{H}^{\prime} \max$, where H'max $=\ln (k), k$ being the number of host plants recorded during the surveys. The total number of all host plants (or total abundance) encountered during a survey was computed in the study area, and the relative abundance of host plants within each agro-ecological zone was also scored. The relative abundance of host plants (based on presence or absence scale) was compared between the different agro-ecological zones using a log-likelihood ratio test or G-test (Zar, 1999). Data of each survey period was analyzed separately as the variances were heterogeneous. The homogeneity of the diversity indices from the different AEZ was assessed using a $t$-test as proposed by Hutcheson (1970).

\section{ACKNOWLEDGEMENTS}

This work was supported by a U.S. Agency for International Development (program on Biotechnology and Biodiversity Interface) grant no. GDG-G-00-0100016-00 to EOO. The authors thank Daniel Mungai for technical assistance and Simon Mathenge (Botany Department, University of Nairobi) for identification of plant specimens.

Received June 14, 2004; accepted January 10, 2005. 


\section{REFERENCES}

Agnew AD, Agnew S (1994) Upland Kenya wild flowers. A flora of the ferns and herbaceous flowering plants of upland Kenya. East Africa Natural History Society, Nairobi, Kenya, pp 10-112

Arc View 3.2 (1992) Environmental Systems Research Institute, New York

Beentje HJ (1994) Kenya Trees Shrubs and Lianas. National Museums of Kenya, Nairobi, pp 43-627

Brousseau R, Masson L, Hegedus D (1999) Insecticidal transgenic plants: are they irresistible? AgbiotechNet Vol. I, July ABN 022

Food and Agriculture Organisation (FAO) (2001) FAO Production Yearbook 2000. FAO statistics series No. 2, Rome

Gould F, Tabashnik BE (1998) Bt-cotton resistance management. In Mellon M, Rissler J, eds, Now or never: serious new plans to save a natural pest control, Union of Concerned Scientists, Cambridge, pp 67-105

Grieg-Smith P (1983) Quantitative plant ecology. Blackwell Scientific, Oxford, pp 8-10

Hutcheson K (1970) A test for comparing diversities based on the Shannon formula. J. Theoret. Biol. 29: 151-154

Innes GM, Kay M (1977) The value of different supplements to grass silage for fattening beef cattle. Anim. Prod. 24: 152156

Jaetzold R, Schmidt H (1982) Farm management handbook of Kenya, vol. II, parts A, B, \& C. Nairobi. Ministry of Agriculture in cooperation with German Agency of Technical Cooperation, pp 129-189

KARI/CIMMYT (2001) Annual report on Insect Resistant Maize for Africa (IRMA). IRMA document No. 4: 23-26

Khan ZR, Chiliswa P, Ampong NK, Smart LE, Polaszek A, Wandera J, Mulaa MA, Overholt WA (1997) Management of tropical graminaceous stemborers. Insect Sci. Appl. 17: $143-150$

Khan ZR, Pickett JA, Van den Berg J, Wadhams LJ, Woodock CM (2000) Exploiting chemical ecology and species diversity stemborer and Striga control for maize and sorghum in Africa. Pest Manag. 12: 221-224

Koziel MG, Beland GL, Bowman C, Carozzi NB, Crenshaw R, Crossland E, Rhodes R, Warren GW, Wright M, Evola SV (1993) Field performance of elite transgenic maize plants expressing an insecticidal protein derived from Bacillus thuringiensis. Biotechnology 11: 194-200

Magurran AE (1988) Ecological diversity and its measurement. Princeton university press, Princeton

Ndemah RS, Gounou S, Schulthess F (2002) The role of wild grasses in the management of lepidopterous stemborers on maize in the humid tropics of western Africa. Bull. Entomol. Res. 92: 507-519
Ofomata VC, Overholt WA, Lux SA, Van Huis A, Egwuatu I (2000) Comparative studies on the fecundity, egg survival, larval feeding and development of Chilo partellus and Chilo orichalcociliellus (Lepidoptera: Crambidae) on five grasses. Ann. Entomol. Soc. 93: 492-499

Overholt WA, Ngi-Song AJ, Kimani SW, Mbapila J, Lammers PM, Kioko E (1994) Ecological considerations of the introduction of Cotesia flavipes Cameron (Hymenoptera: Braconidae) for biological control of $C$. partellus (Swinhoe) (Lepidoptera: Pyralidae), in Africa. Biocont. News Info. 15: 19-24

Overholt WA, Conlong DE, Kfir R, Schulthess F, Setamou M (2003) Biological control of gramineous lepidopteran stem borers in Sub-saharan Africa. In Neuenschwwander P, Borgemeister C, Langewald J, eds, Biological Control in IPM Systems in Africa, Wallingford, CAB International, Great Britain, pp 131-144

Patil GP, Taillie C (1977) Diversity as a concept and its implications for random communities. Bull. Int. Statist. Inst. 47: 497-515

Persley G (2002) Agricultural Biotechnology: Global Challenges and Emerging Science. In Persley G, MacIntyre LR, eds, Agricultural Biotechnology: Country Case Studies A Decade of Development, Wallingford, CAB International, Great Britain, pp 3-37

Rebe M, Van den Berg J (2001) Wild host plants of lepidopterous stem borers stemborers in the Limpopo and northern Mpumalanga provinces of South Africa. Pietermaritzburg, pp 2-3

Scheltes P (1978) Ecological and physiological aspects of aestivation-diapause in the larvae of two pyralid stalk borers of maize in Kenya. Landbouwhoge School, Wageningen, pp 7-11

Schulthess F, Bosque-Perez NA, Chabi-Olaye A, Gounou S, Ndema R, Georgen G (1997) Exchange of natural enemies of lepidopteran cereal stemborers between African regions. Insect Sci. Appl. 17: 97-108

Sétamou M, Schulthess F, Bosque-Perez NA, Thomas-Odjo A (1993) Effect of plant nitrogen and silica on the bionomics of Sesamia calamistis Hampson (Lepidiptera: Noctuidae). Bull. Entomol. Res. 83: 405-411

Sombroek WC, Antoine J (1994) The use of Geographical Information System (GIS) in Land Resource Appraisal. FAO outlook on agriculture 23: 249-255

Sullian TP, Wagner RG, Pitt DG, Lautenschager RA, Chen DG (1998) Changes in diversity of plant and small mammal communities after herbicide application in sub-boreal spruce forest. Can. J. For. Res. 28: 168-177

Tabashnik BE, Finson N, Johnson MW, Heckel DG (1995) Prolonged selection effects and stability of resistance to Bacillus thuringiensis in diamondback moth (Lepidoptera: Plutellidae). J. Econ. Entomol. 88: 219-224 
Thenya T (2001) Challenges of conservation of dryland shallow waters, Ewaso Narok swamp, Laikipia District wetlands, Kenya. Hydrobiologia 458: 121130

Webster R, Oliver MA (1990) Statistical methods in soil and land resource survey. Oxford University Press
William JS (1996) Ecological Census Techniques. Cambridge University Press, Cambridge

Williams CB (1964) Patterns in the Balance of Nature. Academic press, pp 18-23

Zar JH (1999) Biostatistical Analysis. ED 4. Prentice Hall, New Jersey, pp 40-44

To access this journal online: www.edpsciences.org 